\title{
Factors associated with alcohol, tobacco and illicit drug use among Brazilian undergraduate students
}

\author{
Fatores associados ao uso de álcool, tabaco e drogas ilícitas em estudantes de graduação brasileiros \\ Factores relacionados al uso de alcohol, tabaco y drogas ilícitas en estudiantes de grado brasileños
}

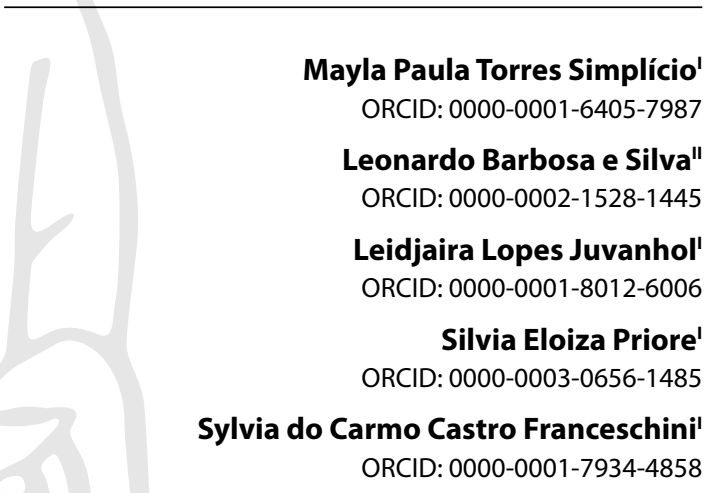

'Universidade Federal de Viçosa. Viçosa, Minas Gerais, Brazil. "Universidade Federal de Uberlândia. Uberlândia,

Minas Gerais, Brazil.

How to cite this article: Simplício MPT, Barbosa e Silva L, Juvanhol LL, Priore SE, Franceschini SCC. Factors associated with alcohol, tobacco and illicit drug use among Brazilian undergraduate students. Rev Bras Enferm. 2021;74(3):e20201244 https://doi.org/10.1590/0034-7167-2020-1244

Corresponding author:

Mayla Paula Torres Simplício E-mail:mayla.simplicio@ufv.br

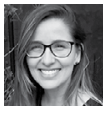

EDITOR IN CHIEF: Antonio José de Almeida Filho ASSOCIATE EDITOR: Álvaro Sousa

Submission: $12-23-2020$

Approval: 03-08-2021

\begin{abstract}
Objectives: to analyze the factors associated with the use of alcohol, tobacco and illicit drugs among Brazilian undergraduate students. Methods: observational, cross-sectional study, with convenience sampling, conducted in 2014/2015, involving institutional data and a self-completed online questionnaire, analyzed using measures of frequency, central tendency/dispersion and logistic regression. Results: among 126,326 students, 62.8\% reported alcohol use; $11 \%$, tobacco; and $7.5 \%$, illicit drugs. Several academic factorssuch as not residing with family (sororities [alcohol: aOR:2.38;95\% $\mathrm{Cl}: 2.28-2.48$; tobacco: AOR:2.20;95\%Cl:2.09-2.33; illicit drugs: AOR:2.53;95\%Cl:2.38-2.70]), acting in university movements (student [alcohol: AOR:1.74;95\%Cl:1.65-1.83; tobacco: AOR:1.97;95\%Cl:1.86-2.08; illicit drugs: AOR:2.43;95\%Cl:2.28-2.59] and religious [alcohol: AOR:0.28;95\%Cl:0.26-0.29; tobacco: AOR:0.23;95\%Cl:0.21-0.26; illicit drugs: AOR:0.18;95\%Cl:0.16-0.21]) and lack of discipline/study habit (alcohol: AOR:1.41;95\%Cl:1.37-1.45; tobacco: AOR:1.53;95\%Cl:1.46-1.59; illicit drugs: AOR:1.85;95\%Cl:1.76-1.94) - were associated with the use of the three categories of substances. Conclusions: we identified that a number of academic factors are associated with licit and illicit drug use. These findings may help in designing preventive strategies among college students. Descriptors: Public Health; Universities; Alcohol Drinking in College; Tobacco Use; Illicit Drugs.
\end{abstract}

\section{RESUMO}

Objetivos: analisar os fatores associados ao uso de álcool, tabaco e drogas ilícitas em estudantes de graduação brasileiros. Métodos: estudo observacional, transversal, com amostragem por conveniência, realizado em 2014/2015, envolvendo dados institucionais e questionário on-line autopreenchido, analisados por meio de medidas de frequência, tendência central/dispersão e regressão logística. Resultados: entre 126.326 estudantes, $62,8 \%$ reportaram uso de álcool; $11 \%$, tabaco; e 7,5\%, drogas ilícitas. Diversos fatores acadêmicos - como não residir com a família (repúblicas [álcool: ORa:2,38;IC95\%:2,28-2,48; tabaco: ORa:2,20;IC95\%:2,09-2,33; drogas ilícitas: ORa:2,53;|C95\%:2,38-2,70]), atuar em movimentos universitários (estudantil [álcool: ORa:1,74;|C95\%:1,65-1,83; tabaco: ORa:1,97;|C95\%:1,86-2,08; drogas ilícitas: ORa:2,43;|IC95\%:2,28-2,59] e religioso [álcool: ORa:0,28;IC95\%:0,26-0,29; tabaco: ORa:0,23;IC95\%:0,21-0,26; drogas ilícitas: ORa:0,18;IC95\%:0,16-0,21]) e falta de disciplina/hábito de estudo (álcool: ORa:1,41;|C95\%:1,37-1,45; tabaco: ORa:1,53;|C95\%:1,46-1,59; drogas ilícitas: ORa:1,85;|C95\%:1,76-1,94) - foram associados ao uso das três categorias de substâncias. Conclusões: identificamos que uma série de fatores acadêmicos estão associados ao consumo de drogas lícitas e ilícitas. Esses achados podem ajudar a elaborar estratégias preventivas entre universitários. Descritores: Saúde Pública; Universidades; Consumo de Álcool na Faculdade; Uso de Tabaco; Drogas llícitas.

\section{RESUMEN}

Objetivos: analizar factores relacionados al uso de alcohol, tabaco y drogas ilícitas en graduandos brasileños. Métodos: estudio observacional, transversal, con muestreo por conveniencia, realizado en 2014/2015, envolviendo datos institucionales y encuesta en línea autorellenado, analizados por medio de medidas de frecuencia, tendencia central/dispersión y regresión logística. Resultados: entre 126.326 estudiantes, 62,8\% reportaron uso de alcohol $11 \%$, tabaco; y 7,5\%, drogas ilícitas. Diversos factores académicos - como no residir con la familia (repúblicas [alcohol: Ora:2,38;IC95\%:2,28-2,48; tabaco: Ora:2,20;IC95\%:2,09-2,33; drogas ilícitas: Ora:2,53;IC95\%:2,38-2,70]), actuar en movimientos universitarios (estudiantil [alcohol: Ora:1,74;|C95\%:1,65-1,83; tabaco: Ora:1,97;|C95\%:1,86-2,08; drogas ilícitas:Ora:2,43;|C95\%:2,28-2,59] y religioso [alcohol: Ora:0,28;IC95\%:0,26-0,29; tabaco: Ora:0,23;IC95\%:0,21-0,26; drogas ilícitas: Ora:0,18;|C95\%:0,16-0,21]) y falta de disciplina/hábito de estudio (alcohol:Ora:1,41;|C95\%:1,37-1,45; tabaco: Ora:1,53;|C95\%:1,46-1,59; drogas ilícitas: Ora:1,85;|C95\%:1,76-1,94) — relacionados al uso de tres categorías de substancias. Conclusiones: identificamos que una serie de factores académicos están relacionados al consumo de drogas lícitas e ilícitas. Esos hallados pueden ayudar a elaborar estrategias preventivas entre universitarios.

Descriptores: Salud Pública; Universidades; Consumo de Alcohol en la Universidad; Uso de Tabaco; Drogas llícitas. 


\section{INTRODUCTION}

Entering university presents itself as a decisive phase in the student's life, increasing his/her autonomy and freedom and, consequently, providing more access to health risk elements ${ }^{(1)}$. Studies have identified higher consumption of alcohol, tobacco and other drugs among college students compared to the average of the general population ${ }^{(1-3)}$.

A review of the literature with Brazilian students signaled that the university environment is a motivator for substance use ${ }^{(4)}$. The association between exposure to the university environment and alcohol use and related disorders was also assessed in a populationbased sample of twins $(n=787)$ : women who attended university consumed more alcohol than their non-college peers ${ }^{(5)}$.

According to the World Health Organization (WHO), Brazil has a higher per capita consumption of alcohol than the average of the American continent (8.7 vs. 8.4 liters of alcohol/year) $)^{(6)}$; and, among college students, the consumption of this substance has been shown to be even higher, both in Brazil( ${ }^{(7-8)}$ as in other countries of the world ${ }^{(9)}$. A worrisome fact is the increase in alcohol use in this population over the past few years, with higher rates of binge drinking and drunkenness than previous generations ${ }^{(9)}$. The WHO also estimates that the prevalence of smoking among people aged 15 years and older is $22.7 \%$ worldwide ${ }^{(10)}$ and that smoking (active or passive) is responsible for the death of about 6 million people a year worldwide ${ }^{(11)}$. Among college students, these figures are also high, and an increase in the frequency of smoking was identified in this population from the 1990s to the $2000 \mathrm{~s}^{(12)}$. Among Brazilian college students, illicit drugs (drugs manufactured, obtained or sold illegally) ${ }^{(13)}$ most cited as having ever used in their lives are inhalants, marijuana, anxiolytics, and amphetamines; it was also found that Brazilian college students use almost twice as many inhalants as American students ${ }^{(3)}$.

Given this scenario, the use of such substances among university students has been considered a public health problem worldwide; and, in Brazil, according to the last Census of Higher Education, in 2019, there were 8,604,526 enrollments in higher education $^{(14)}$. Nursing is an essential profession and considered nuclear in the structure of health professions, with a contingent of more than 2 million professionals in Brazil, is present in all organizational structures of the Brazilian health system (hospitals, outpatient clinics, Primary Health Care Units, etc.) and operates in the various dimensions of health (health care, public health, prevention, and health promotion) ${ }^{(15)}$. Its multi-functionality has allowed the expansion of spaces for professionals, working in processes, coordination and health care within Brazilian federal educational institutions. Thus, the role of nursing professionals, inside and outside of academic environments, is essential to control the use of alcohol, tobacco and illicit drugs among college students.

However, although knowledge about the relationship between university life and students' health is fundamental for the formulation of interventions and policies, studies on the subject are still limited. The vast majority of published studies assess few academic factors; are limited to specific courses or institutions and small samples; and are conducted in restricted countries, especially developed ones. Thus, the following research question arises:
"What academic factors are associated with alcohol, tobacco, and illicit drug use?" Our hypothesis is that several academic factors are associated with the consumption of these substances.

\section{OBJECTIVES}

To analyze the factors associated with the use of alcohol, tobacco and illicit drugs among undergraduate students of Brazilian federal institutions.

\section{METHODS}

\section{Ethical aspects}

This research obtained the approval of the National Association of Directors of Federal Institutions of Higher Education $\left(\right.$ ANDIFES) ${ }^{(16)}$ for use of the database and the Ethics Committee for Research with Human Beings of the Universidade Federal de Viçosa (Federal University of Viçosa).

\section{Design, period and place of study}

Observational, cross-sectional study, with convenience sampling, guided by the STROBE tool, conducted in 62 Brazilian federal institutions between September 2014 and February 2015. It is part of the project "Health of Undergraduate Students of Brazilian Federal Institutions".

\section{Population; criteria of inclusion and exclusion}

The population consisted of undergraduate students (bachelor's degrees, licentiate degrees and technologists) regularly enrolled in on-site courses (all areas) at 62 Brazilian federal institutions in 2014. Considering all the Federal Institutions of Higher Education (IFES) and Federal Centers of Technological Education (CEFET) in the country in that year $(\mathrm{N}=65)$, only three did not participate in this research: the Universidade Federal do Espírito Santo (Federal University of Espírito Santo) and the Universidade Federal de Ciências da Saúde de Porto Alegre (Federal University of Health Sciences of Porto Alegre), which did not provide the necessary records for their students to have access to the data collection system; and the Universidade Federal do Oeste da Bahia (Federal University of Western Bahia), due to its recent foundation (in 2013). Thus, the study included 20 IFES/CEFET from the Southeast, 17 from the Northeast, ten from the North, ten from the South, and five from the Center-West $(n=62)$; the Federal District and all Brazilian states participated, with the exception of Espírito Santo.

The inclusion criterion for the survey was to be an undergraduate student regularly enrolled in in-class courses at one of the 62 IFES/CEFET in 2014 (data provided by the educational institutions; $N=939,604$ ). Students who had blank questions in their questionnaires were excluded.

\section{Study protocol}

The data for this study was collected by ANDIFES and the National Forum of Pro-Rectors for Community and Student Affairs (FONAPRACE) ${ }^{(17)}$, through the "IV Survey of the Socioeconomic 
and Cultural Profile of Undergraduate Students at Brazilian Higher Education Federal Institutions ${ }^{(16)}$. The research was carried out by the Center for Social-Economic Research (CEPES), a complementary body of the Institute of Economics of the Universidade Federal de Uberlândia (Federal University of Uberlândia) (FUU), as requested by FONAPRACE, through an online questionnaire filled out by the students themselves (available at: $h t t p: / / w w w$. andifes.org.br/wp-content/uploads/2017/11/Pesquisa-de-Perfildos-Graduanso-das-IFES_2014.pdf) ${ }^{(18)}$.

The only information provided by the educational institutions, and not by the self-completion of the online questionnaire, were: e-MEC code; Federation Unit and city of the IFES/CEFET; e-MEC code of the course and CPF (transformed into an individual identification code); gender; date and city of birth; and year of student entry.

Between September and December 2014, information was provided by the educational institutions, allowing access to the online system. Between November 18, 2014 and February 1,2015 , students accessed the online questionnaire (with the possibility of linking it to the institution's enrollment systems) and self-completed it.

Use of alcoholic beverages, tobacco or illicit drugs were the dependent variables analyzed by the study. The students answered the questions: "How often do you use alcoholic beverages?", "How often do you use tobacco (cigarette or other)?" and "How often do you use non-licit drugs?". The presence of substance use was indicated by the choice of the answers "on weekends", "several times a week", "every day" or "occasionally"; while the absence of use was indicated by the answer "never".

The academic factors (independent variables) were: academic year; area and shift of the course; characterization of the campus as headquarter or advanced; mode of admission to the educational institution (wide competition or quota); time spent outside class studying; participation in academic activities/programs; enrollment in a course that corresponds to the first option; intention to change course; type of housing; participation in medical and/or psychological care provided by student assistance; participation in a student assistance program in the areas of culture and/or sports and leisure; provision, by the university, of conditions to perform any of its physical activities; preferred network of medical care; participation in artistic-cultural, ecological, student, religious, and/or political movements; and difficulties with significant interference in life or in the academic context (adaptation to new situations [city, housing, distance from family, others], difficulties in access to materials and means of study [books, computer, others], financial difficulties, learning difficulties, lack of discipline/ study habits, excessive student workload, or difficulty in the teacher-student relationship).

The sociodemographic variables used in this study for adjustment purposes were: age, sex, color/race and marital status of the student; maternal education; gross family income per capita (estimated); paid work performed by the student; report of having children; and location of the campus in the state capital or interior. The variables gross family income and number of people dependent on income were informed by the students in ranges. Subsequently, to calculate the gross family income per capita, the average values of the salary ranges were adopted (e.g., from "one to two minimum wages", income of 1.5 minimum wages was considered). For the range "above ten minimum wages" of gross family income, the value of 10.5 minimum wages was adopted; and for the range "nine or more" of the number of people dependent on the income, the value of ten people.

\section{Analysis of results and statistics}

The sample was characterized using measures of frequency (absolute and relative), central tendency, and dispersion. To identify the factors associated with the use of alcohol, tobacco, and illicit drugs, we used crude and adjusted logistic regression. Based on the crude analysis, explanatory variables with $p$-value $<0.20$ were inserted by the backward method in the adjusted model, and those with lower significance (higher $p$-value) were removed one by one from the model. The procedure was repeated until all variables in the model were statistically significant $(p<$ 0.05). In the adjusted model, the sociodemographic variables described above were also included for adjustment purposes. The Hosmer \& Lemeshow test was used to verify the adequacy of the final model. The odds ratio (OR), with a $95 \%$ confidence interval $(95 \% \mathrm{Cl})$, was used as a measure of association. Data was analyzed using SPSS (version 20.0) and Stata (version 13.0) software.

\section{RESULTS}

At the end of the survey, a sample of 126,326 undergraduate students regularly enrolled in in-class courses at 62 Brazilian Federal Institutions in 2014 was reached (131,662 respondents; 5,336 excluded). Among these, the use of alcohol, tobacco, and illicit drugs was cited by, respectively, $62.8 \%(n=79,293), 11 \%$ ( $n=13,947)$, and $7.5 \%(n=9,429)$ of students. Table 1 describes the sociodemographic profile of the participants.

The crude and adjusted logistic regression models on the use of alcohol, tobacco and illicit drugs are presented in Table 2. Higher odds of using the three categories of substances were identified among college students who did not reside with family (highlighting sororities [alcohol: AOR: 2.38; 95\%Cl: 2.28-2.48; tobacco: AOR: 2.20; 95\%Cl: 2.09-2.33; and illicit drugs: AOR: 2.53 ; $95 \% \mathrm{Cl}: 2.38-2.70$ ] and university housing [alcohol: AOR: $1.8 ; 95 \% \mathrm{Cl}$ : 1.68-1.98; tobacco: AOR: 1.83; 95\%Cl: 1.64-2.05; and illicit drugs: AOR: 2.53 ; 95\%Cl: 2.23-2.87]), were active in artistic-cultural (highlighting illicit drugs [AOR: $2.45 ; 95 \% \mathrm{Cl}$ : 2.27-2.65]), ecological, student (highlighting illicit drugs [AOR: 2.43; 95\%Cl: 2.28-2.59]) and political; participated in activities in student assistance in culture; had doubts about changing courses; and reported difficulties involving teacher-student relationship, financial issues or lack of discipline/study habit.

The students with longer university time, from the agricultural sciences, from night courses, students enrolled by quota, participants in academic programs, and those who reported student assistance through medical care or university conditions for physical activities were also more likely to use alcohol.

Additionally, students from the Humanities (AOR: $2.19 ; 95 \% \mathrm{Cl}$ : 2.03-2.37), who were not enrolled in courses corresponding to their first choice, with the intention to change courses, and who participated in medical or psychological consultations of the student assistance had a higher chance of tobacco use. 
Table 1 - Sociodemographic profile of undergraduate students from 62 Federal Institutions of Higher Education/Federal Centers of Technological Education, Brazil, 2014, ( $N=126,326)$

\begin{tabular}{|c|c|}
\hline Variables & $\%(n)$ \\
\hline Age (years) & $24.0 \pm 6.5^{\mathrm{a}}$ \\
\hline \multicolumn{2}{|l|}{ Sex } \\
\hline Male & $42.9(54,147)$ \\
\hline Female & $57.0(71,987)$ \\
\hline Not declared & $0.2(192)$ \\
\hline \multicolumn{2}{|l|}{ Color or race } \\
\hline White & $44.9(56,667)$ \\
\hline Yellow & $2.3(2,879)$ \\
\hline Brown & $38.7(48,846)$ \\
\hline Black & $9.8(12,339)$ \\
\hline Indigenous & $0.6(764)$ \\
\hline Not declared & $3.8(4,831)$ \\
\hline \multicolumn{2}{|l|}{ Mother's education level } \\
\hline Without formal education & $3.7(4,651)$ \\
\hline Incomplete elementar school & $22.4(28,235)$ \\
\hline Complete elementar school & $10.1(12,772)$ \\
\hline Complete Highschool & $34.1(43,113)$ \\
\hline Complete higher education & $19.2(24,196)$ \\
\hline Complete post-graduation & $10.4(13,110)$ \\
\hline No mother or person who played such a role in the upbringing & $0.2(249)$ \\
\hline \multicolumn{2}{|l|}{ Marital status } \\
\hline No partner (single, divorced or widowed) & $88.4(111,706)$ \\
\hline With partner (married or in a stable union) & $11.6(14,620)$ \\
\hline \multicolumn{2}{|l|}{ Gross family income per capita } \\
\hline Up to $1 / 2$ minimum wage & $32.6(41,128)$ \\
\hline$>1 / 2$ up to 1 minimum wage & $22.0(27,798)$ \\
\hline$>1$ up to 2 minimum wages & $24.7(31,265)$ \\
\hline$>2$ up to 3 minimum wages & $13.8(17,379)$ \\
\hline$>3$ up to 4 minimum wages & $4.1(5,195)$ \\
\hline$>4$ up to 5 minimum wages & $0.9(1,182)$ \\
\hline$>5$ up to 6 minimum wages & $1.2(1,539)$ \\
\hline$>6$ up to 7 minimum wages & $0.1(187)$ \\
\hline$>7$ up to 8 minimum wages & $0.1(109)$ \\
\hline$>8$ up to 9 minimum wages & $0.1(101)$ \\
\hline$>9$ up to 10 minimum wages & $0.1(96)$ \\
\hline$>10$ minimum wages & $0.3(347)$ \\
\hline \multicolumn{2}{|l|}{ Paid work } \\
\hline No & $69.5(87,827)$ \\
\hline Yes & $30.5(38,499)$ \\
\hline \multicolumn{2}{|l|}{ Children } \\
\hline No & $89.0(112,368)$ \\
\hline Yes & $11.0(13,958)$ \\
\hline \multicolumn{2}{|l|}{ Location } \\
\hline Capital & $45.6(57,644)$ \\
\hline Countryside & $54.4(68,682)$ \\
\hline
\end{tabular}

The greater chance of illicit drug use was also present among university students with more institutional time, from the Humanities (AOR: $2.55 ; 95 \% \mathrm{Cl}$ : 2.342.78), participants in paid academic programs, with the intention to change course, and who reported student assistance through psychological counseling or university conditions for physical activity.

On the other hand, lower odds of alcohol, tobacco and illicit drug use were also identified among university students from advanced campuses, with more time dedicated outside class to studies (> 15 hours/week), members of religious movements [alcohol (AOR: 0.28; 95\%Cl:0.26-0.29), tobacco (AOR:0.23;95\%Cl:0.21-0.26) and illicit drugs (AOR: $0.18 ; 95 \% \mathrm{Cl}: 0.16-0.21$ )] and who reported difficulties involving learning and adaptation to new situations. Daytime courses, Exact/Earth Sciences and Linguistics/Literatures/Arts, and involving university students with reports of difficulties in access to study materials and means also had a lower chance of alcohol use. The lower use of tobacco was also observed among daytime courses, entrants by quota and with reports of excessive student workload. The lowest use of illicit drugs was identified among the areas of Engineering and Exact/Earth Sciences.

\section{DISCUSSION}

Higher chances of alcohol, tobacco and illicit drug use were identified among students who did not live with their families, were active in artisticcultural, ecological, student and political movements, participated in student assistance activities in culture, had doubts about changing course and reported difficulties involving the teacher-student relationship, financial issues or lack of discipline/ study habit. On the other hand, lower chances of using the three substances were identified among students from advanced campuses, with $>15$ hours/ week of extra-class dedication to studies, members of religious movements, and who reported difficulties involving learning and adaptation to new situations.

Table 2 - Logistic regression models on the use of alcohol, tobacco and illicit drugs among undergraduate students from 62 Federal Institutions of Higher Education/Federal Centers of Technological Education, Brazil, 2014, $(\mathrm{N}=126,326)$

\begin{tabular}{|c|c|c|c|c|c|c|c|}
\hline \multirow[b]{2}{*}{ Explanatory variables } & \multirow[b]{2}{*}{$\%$} & \multicolumn{2}{|c|}{ Alcohol } & \multicolumn{2}{|c|}{ Tobacco } & \multicolumn{2}{|c|}{ Illicit Drugs } \\
\hline & & $\begin{array}{c}\text { Crude } \\
\text { OR(95\%Cl) }\end{array}$ & $\begin{array}{c}\text { Adjusted } \\
\text { OR(95\%Cl) }\end{array}$ & $\begin{array}{c}\text { Crude } \\
\text { OR(95\%Cl) }\end{array}$ & $\begin{array}{c}\text { Adjusted } \\
\text { OR(95\%Cl) }\end{array}$ & $\begin{array}{c}\text { Crude } \\
\text { OR(95\%Cl) }\end{array}$ & $\begin{array}{c}\text { Adjusted } \\
\text { OR(95\%Cl) }\end{array}$ \\
\hline Academic year & $1.8 \pm 1.7^{b}$ & $1.11(1.10-1.12)$ & $1.06(1.05-1.07)$ & $1.05(1.04-1.06)$ & - & $1.06(1.05-1.07)$ & $1.02(1.01-1.04)$ \\
\hline \multicolumn{8}{|l|}{ Area of study } \\
\hline Health Sciences & 14.4 & Ref. & Ref. & Ref. & Ref. & Ref. & Ref. \\
\hline Agricultural Sciences & 7.0 & $1.34(1.27-1.41)$ & $1.20(1.13-1.27)$ & $1.68(1.54-1.83)$ & $1.48(1.35-1.62)$ & $1.27(1.14-1.42)$ & $1.08(0.96-1.21)$ \\
\hline Biological Sciences & 4.7 & $0.97(0.91-1.03)$ & $1.07(1.00-1.14)$ & $1.30(1.17-1.44)$ & $1.34(1.20-1.49)$ & $1.56(1.39-1.76)$ & $1.64(1.45-1.86)$ \\
\hline Exact and Earth Sciences & 14.7 & $0.93(0.89-0.96)$ & $0.82(0.79-0.86)$ & $1.21(1.12-1.31)$ & $1.01(0.93-1.09)$ & $1.07(0.98-1.18)$ & $0.89(0.81-0.99)$ \\
\hline Applied Social Sciences & 20.7 & $1.21(1.16-1.26)$ & $1.09(1.05-1.15)$ & $1.71(1.60-1.83)$ & $1.48(1.37-1.59)$ & $1.79(1.65-1.93)$ & $1.53(1.40-1.67)$ \\
\hline Human Sciences & 15.4 & $1.07(1.03-1.12)$ & $1.12(1.06-1.17)$ & $2.28(2.13-2.44)$ & $2.19(2.03-2.37)$ & $2.44(2.25-2.64)$ & $2.55(2.34-2.78)$ \\
\hline Engineering & 15.8 & $1.49(1.43-1.56)$ & $1.08(1.04-1.14)$ & $1.41(1.31-1.52)$ & $1.00(0.93-1.08)$ & $1.30(1.19-1.42)$ & $0.84(0.77-0.93)$ \\
\hline Linguistics, Letters and Arts & 7.4 & $0.84(0.80-0.88)$ & $0.87(0.82-0.92)$ & $1.99(1.84-2.16)$ & $1.85(1.70-2.03)$ & $2.00(1.81-2.20)$ & $1.99(1.79-2.21)$ \\
\hline
\end{tabular}




\begin{tabular}{l} 
Explanatory variables \\
\\
\hline Campus \\
Headquarters \\
Advanced \\
Shift \\
Full time \\
Day \\
Night \\
Admission modality \\
Broad competition \\
Quota \\
Time spent out of class studying \\
Up to 5 hours/week \\
$>5$ to 10 hours/week \\
$>10$ to 15 hours/week \\
$>15$ to 20 hours/week \\
$>20$ to 25 hours/week \\
$>25$ hours/week \\
Participation in academic activities or programs \\
No \\
Yes (Unpaid) \\
Yes (Paid) \\
Enrolled in a course that corresponds to your \\
first choice \\
Yes \\
No \\
Intention to change course \\
Yes \\
No \\
Doesn't know \\
Type of housing \\
With family (parents, spouse or relatives) \\
Alone \\
University housing \\
Communal living \\
Other (boarding house, hotel, boarding \\
house, rooming house or in a friend's house) \\
Participation in student assistance psychological \\
Yonsultations \\
Yo \\
Yes \\
Pation in student health care services \\
Pation \\
Po
\end{tabular}

Participation in a student care program in the area of culture No

Yes

Participation in a student care program in the area of sports and leisured No

Yes

Provision, by the university, of conditions for the realization of some of its physical activities No

Yes

Preferred medical care network

Public, informal help from friends or family, or none

Private network (no health insurance plan) Private network (with health insurance plan) Health services offered by the university itself

Participation in an artistic-cultural movement

No

Yes

Participation in ecological movement No

Yes

\begin{tabular}{|c|c|c|c|c|c|}
\hline & hol & & CCO & Illici & rugs \\
\hline $\begin{array}{c}\text { Crude } \\
\text { OR(95\%Cl) }\end{array}$ & $\begin{array}{l}\text { Adjusted } \\
\text { OR(95\%Cl) }\end{array}$ & $\begin{array}{c}\text { Crude } \\
\text { OR(95\%Cl) }\end{array}$ & $\begin{array}{c}\text { Adjusted } \\
\text { OR(95\%CI) }\end{array}$ & $\begin{array}{c}\text { Crude } \\
\text { OR(95\%Cl) }\end{array}$ & $\begin{array}{c}\text { Ádjusted } \\
\text { OR(95\%Cl) }\end{array}$ \\
\hline
\end{tabular}

$\begin{array}{ccccccc}72.3 & \text { Ref. } & \text { Ref. } & \text { Ref. } & \text { Ref. } & \text { Ref. } & \text { Ref. } \\ 27.7 & 0.82(0.80-0.84) & 0.79(0.76-0.82) & 0.76(0.73-0.79) & 0.80(0.76-0.85) & 0.66(0.63-0.70) & 0.82(0.77-0.87\end{array}$

$\begin{array}{lccccc}43.1 & \text { Ref. } & \text { Ref. } & \text { Ref. } & \text { Ref. } & \text { Ref. } \\ 28.2 & 0.77(0.75-0.79) & 0.94(0.91-0.97) & 0.97(0.93-1.01) & 0.94(0.90-0.99) & 0.98(0.94-1.04) \\ 28.7 & 0.90(0.88-0.93) & 1.06(1.02-1.09) & 1.15(1.10-1.20) & 1.04(0.99-1.09) & 1.00(0.95-1.05)\end{array}$

$\begin{array}{cccccc}66.5 & \text { Ref. } & \text { Ref. } & \text { Ref. } & \text { Ref. } & \text { Ref. } \\ 33.5 & 0.78(0.77-0.80) & 1.04(1.01-1.07) & 0.78(0.75-0.81) & 0.93(0.89-0.97) & 0.76(0.73-0.80)\end{array}$

32.5 Ref. $\quad$ Ref. $\quad$ Ref. $\quad$ Ref. $\quad$ Ref. Ref.

$29.6 \quad 1.08(1.05-1.11) \quad 1.05(1.01-1.08) \quad 0.92(0.88-0.96) \quad 0.94(0.90-0.98) \quad 0.91(0.86-0.96) \quad 0.90(0.85-0.95)$

$\begin{array}{lllllll}14.8 & 1.05(1.02-1.09) & 1.01(0.97-1.05) & 0.82(0.77-0.87) & 0.83(0.78-0.88) & 0.78(0.73-0.83) & 0.75(0.70-0.80)\end{array}$

$\begin{array}{lllllll}10.1 & 0.97(0.93-1.01) & 0.92(0.88-0.96) & 0.77(0.72-0.82) & 0.80(0.75-0.86) & 0.66(0.60-0.71) & 0.64(0.59-0.71)\end{array}$

$\begin{array}{lllllll}6.1 & 0.84(0.80-0.89) & 0.81(0.76-0.85) & 0.66(0.60-0.71) & 0.71(0.65-0.78) & 0.62(0.56-0.68) & 0.63(0.56-0.71)\end{array}$

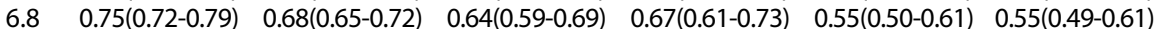

50.7 Ref. $\quad$ Ref. $\quad$ Ref. $\quad$ - $\quad$ Ref.

$\begin{array}{lllllll}17.1 & 1.43(1.38-1.47) & 1.15(1.11-1.19) & 1.20(1.14-1.26) & - & 1.31(1.23-1.39) & 0.98(0.92-1.04)\end{array}$

$\begin{array}{llllll}32.1 & 1.31(1.28-1.34) & 1.14(1.11-1.18) & 1.15(1.10-1.20) & - & 1.41(1.34-1.47) \\ 1.11(1.05-1.17)\end{array}$

84.9 Ref. $\quad$ - $\quad$ Ref. $\quad$ Ref. $\quad$ Ref

$\begin{array}{llllll}15.1 & 0.91(0.88-0.94) \quad-\quad & 1.05(1.00-1.10) & 1.08(1.03-1.14) & 0.96(0.90-1.02)\end{array}$

61.4 Ref. $\quad$ Ref. $\quad$ Ref. $\quad$ Ref. Ref.

$20.2 \quad 0.91(0.89-0.94) \quad 1.01(0.98-1.04) \quad 1.13(1.08-1.18) \quad 1.14(1.09-1.20) \quad 1.10(1.04-1.16) \quad 1.14(1.07-1.20)$

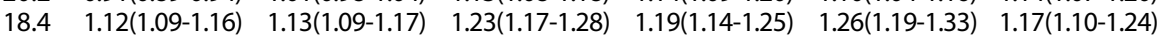

65.9 Ref. $\quad$ Ref. $\quad$ Ref. $\quad$ Ref. $\quad$ Ref. Ref.

$10.2 \quad 1.68(1.61-1.75) \quad 1.38(1.32-1.45) \quad 1.63(1.54-1.73) \quad 1.42(1.33-1.51) \quad 1.46(1.36-1.57) \quad 1.39(1.29-1.50)$

$\begin{array}{lllllll}2.6 & 1.74(1.61-1.88) & 1.82(1.68-1.98) & 1.81(1.65-2.00) & 1.83(1.64-2.05) & 2.30(2.07-2.56) & 2.53(2.23-2.87)\end{array}$

$15.0 \quad 2.68(2.58-2.78) \quad 2.38(2.28-2.48) \quad 2.18(2.09-2.28) \quad 2.20(2.09-2.33) \quad 2.37(2.26-2.50) \quad 2.53(2.38-2.70)$

$6.2 \quad 1.33(1.26-1.39) \quad 1.47(1.39-1.55) \quad 1.20(1.11-1.30) \quad 1.33(1.23-1.45) \quad 1.34(1.23-1.47) \quad 1.62(1.47-1.79)$

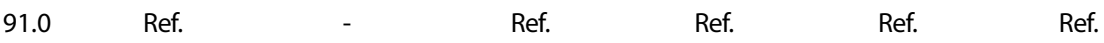

$\begin{array}{llllll}9.0 & 1.23(1.16-1.30) \quad-\quad & 1.50(1.40-1.62) & 1.22(1.12-1.32) & 1.36(1.28-1.46) & 1.33(1.21-1.46)\end{array}$

95.3 Ref. $\quad$ Ref. $\quad$ Ref. $\quad$ Ref.

$4.7 \quad 1.29(1.24-1.34) \quad 1.12(1.06-1.18) \quad 1.33(1.26-1.41) \quad 1.10(1.03-1.18) \quad 1.69(1.55-1.83)$

90.6 Ref. $\quad$ Ref. $\quad$ Ref. $\quad$ Ref. $\quad$ Ref. $\quad$ Ref.

$9.4 \quad 1.36(1.31-1.42) \quad 1.16(1.11-1.22) \quad 1.60(1.52-1.69) \quad 1.25(1.18-1.33) \quad 1.87(1.77-1.99) \quad 1.29(1.21-1.38)$

96.2 Ref. $\quad$ - Re

$3.8 \quad 1.39(1.31-1.48)$

75.8 24.

53.9 Ref. Ref. Ref.

$\begin{array}{llll}4.8 & 1.24(1.18-1.31) & 1.05(0.99-1.12) & 1.00(0.91-1.09)\end{array}$

$38.1 \quad 1.60(1.56-1.64) \quad 1.15(1.12-1.19) \quad 1.22(1.17-1.27)$

$3.2 \quad 1.52(1.42-1.63) \quad 0.97(0.89-1.05) \quad 1.39(1.27-1.53)$

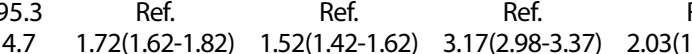

98.0 Ref. $\quad$ Ref. $\quad$ Ref. $\quad$ Ref. $\quad$ Ref.

$2.0 \quad 1.50(1.37-1.63) \quad 1.13(1.03-1.25) \quad 2.33(2.12-2.57) \quad 1.34(1.20-1.49) \quad 3.43(3.11-3.78) \quad 1.87(1.66-2.10)$
Ref. $1.54(1.40-1.69)$

Ref. 1.32(1.26-1.39) $1.07(1.02-1.13)$

Ref. Ref 0.94(0.84-1.05) $0.85(0.75-0.95)$ $1.41(1.35-1.47) \quad 1.00(0.95-1.06)$ $1.63(1.47-1.82) \quad 1.05(0.93-1.19)$

Ref. Ref. 7-2.65) 


\begin{tabular}{l} 
Explanatory variables \\
\hline Participation in student movement \\
No \\
Yes \\
Participation in religious movement \\
No \\
Yes \\
Participation in political party \\
No \\
Yes
\end{tabular}

Difficulties with significant interference in life or academic context:

Difficulties in adapting to new situations (city, housing, distance from family, among others) No Yes

Difficulty in access to materials and means of study (books, computer, other) No
Yes

Financial difficulties

No

Yes

Learning Difficulty

No

Yes

Lack of discipline/study habit

No

Yes

Excessive student workload

No

Yes

Difficulties in the teacher-student relationship No

Yes
Alcohol

Alcohol Tobacco

Adjusted

OR(95\%Cl)

OR(95\%Cl)

Ref.
$7(2.64-2.91)$

Ref.

Ref.

$\begin{array}{cc}91.7 & \text { Ref. } \\ 8.3 & 0.29(0.28-0.3\end{array}$

Ref.

$0.25(0.22-0.28)$

$0.23(0.21-0.26)$

Ref.

Ref.

Ref.

1.56(1.41-1.73)

Ref.

Ref.

Ref.

$2.1 \quad 2.08(1.90-2.28)$

1.70(1.54-1.88)

$2.79(2.55-3.05)$

3.24(2.94-3.57)

Illicit Drugs

Crude Adjusted

OR(95\%Cl)

OR $(95 \% \mathrm{CI})^{\mathrm{a}}$

22.3

$\begin{array}{cccccc}\text { Ref. } & \text { Ref. } & \text { Ref. } & \text { Ref. } & \text { Ref. } & \text { Ref. } \\ 1.14(1.11-1.17) & 0.95(0.92-0.99) & 1.12(1.07-1.16) & 0.93(0.89-0.97) & 1.16(1.11-1.22) & 0.90(0.85-0.95)\end{array}$

$\begin{array}{cccccc}\text { Ref. } & \text { Ref. } & \text { Ref. } & \text { Ref. } & \text { Ref. } & \text { Ref. } \\ 1.14(1.11-1.17) & 0.95(0.92-0.99) & 1.12(1.07-1.16) & 0.93(0.89-0.97) & 1.16(1.11-1.22) & 0.90(0.85-0.95)\end{array}$

$\begin{array}{cccccc}\text { Ref. } & \text { Ref. } & \text { Ref. } & \text { Ref. } & \text { Ref. } & \text { Ref. } \\ 1.14(1.11-1.17) & 0.95(0.92-0.99) & 1.12(1.07-1.16) & 0.93(0.89-0.97) & 1.16(1.11-1.22) & 0.90(0.85-0.95)\end{array}$

$\begin{array}{cccccc}\text { Ref. } & \text { Ref. } & \text { Ref. } & \text { Ref. } & \text { Ref. } & \text { Ref. } \\ 1.14(1.11-1.17) & 0.95(0.92-0.99) & 1.12(1.07-1.16) & 0.93(0.89-0.97) & 1.16(1.11-1.22) & 0.90(0.85-0.95)\end{array}$

$\begin{array}{cccccc}\text { Ref. } & \text { Ref. } & \text { Ref. } & \text { Ref. } & \text { Ref. } & \text { Ref. } \\ 1.14(1.11-1.17) & 0.95(0.92-0.99) & 1.12(1.07-1.16) & 0.93(0.89-0.97) & 1.16(1.11-1.22) & 0.90(0.85-0.95)\end{array}$

$\begin{array}{cccccc}\text { Ref. } & \text { Ref. } & \text { Ref. } & \text { Ref. } & \text { Ref. } & \text { Ref. } \\ 1.14(1.11-1.17) & 0.95(0.92-0.99) & 1.12(1.07-1.16) & 0.93(0.89-0.97) & 1.16(1.11-1.22) & 0.90(0.85-0.95)\end{array}$

81.9 Ref. Ref. $\quad$ Ref.

$18.1 \quad 0.86(0.83-0.88) \quad 0.91(0.88-0.95) \quad 1.05(1.01-1.10)$

Ref.
$1.07(1.01-1.13)$

$\begin{array}{ccccccc}58.9 & \text { Ref. } & \text { Ref. } & \text { Ref. } & \text { Ref. } & \text { Ref. } & \text { Ref. } \\ 41.1 & 0.93(0.91-0.95) & 1.20(1.17-1.23) & 1.17(1.13-1.21) & 1.32(1.27-1.38) & 1.12(1.07-1.17) & 1.29(1.23-1.36)\end{array}$

83.7 Ref. $\quad$ Ref. $\quad$ Ref. $\quad$ Ref. $\quad$ Ref. $\quad$ Ref.

$\begin{array}{lllllll}16.3 & 0.92(0.89-0.95) & 0.94(0.91-0.97) & 0.96(0.91-1.00) & 0.94(0.89-0.99) & 0.94(0.89-1.00) & 0.92(0.86-0.98)\end{array}$

71.2 Ref. $\quad$ Ref. $\quad$ Ref. Ref. $\quad$ Ref. Ref.

$28.8 \quad 1.65(1.61-1.70) \quad 1.41(1.37-1.45) \quad 1.80(1.73-1.87) \quad 1.53(1.46-1.59) \quad 2.35(2.25-2.45) \quad 1.85(1.76-1.94)$

$\begin{array}{lccccc}69.8 & \text { Ref. } & - & \text { Ref. } & \text { Ref. } & \text { Ref. } \\ 30.2 & 1.06(1.03-1.08) & - & 0.93(0.89-0.96) & 0.90(0.87-0.94) & 1.01(0.96-1.06)\end{array}$

81.0 Ref. $\quad$ Ref. $\quad$ Ref. $\quad$ Ref. $\quad$ Ref. Ref

$19.0 \quad 1.33(1.30-1.38) \quad 1.14(1.10-1.18) \quad 1.32(1.27-1.38) \quad 1.14(1.09-1.20) \quad 1.47(1.40-1.54) \quad 1.17(1.10-1.23)$

Note: ${ }^{a}$ adjusted analyses according to age, sex, color/race, maternal education, marital status, gross family income per capita, having paid jobs and children, and university location (capital or interior); ${ }^{b}$ mean \pm standard deviation; ${ }^{c}$ junior enterprise, internship, PET (Tutorial Education Program) or teaching activities/programs (monitoring, PIBID, PLI etc.), extension (PIBEXT, PEIC etc.) and research (PIBIC, PIBIT etc.); ${ }^{d}$ scholarship, financial support for participation in activities, acquisition of materials or sports and leisure activities offered by the institution (previous or current); OR: odds ratio; C195\%: $95 \%$ confidence interval; Ref: reference category; $p<0.05$ in bold.

Other national studies have identified higher prevalence of lifetime use of alcohol, tobacco and illicit drugs than those found in this study ${ }^{(19-20)}$. It is revealed that alcohol, tobacco and illicit drug consumption become higher as the academic years go by ${ }^{(8)}$ (similar to that observed for alcohol and illicit drugs). The college population is more vulnerable to initiation and maintenance of alcohol, tobacco and illicit drug use due to the possibilities of purchase, greater availability of consumption situations, the recent independence and autonomy acquired and, in many occasions, the lack of parental control ${ }^{(3,21)}$. Similarly, it is pointed out that living with a family would be a protective factor for the use of the three categories of substances ${ }^{(4-22)}$.

To our knowledge, this is the first study to evaluate the association between the consumption of alcohol, tobacco and illicit drugs and university movements. Another study also identified higher use of tobacco and illicit drugs among university students in the Humanities ${ }^{(23)}$. It is noteworthy, however, that although Health Sciences courses have greater access to information, less alcohol use was identified among Exact/Earth Sciences and Linguistics/Literatures/Arts courses, and less use of illicit drugs among Engineering and Exact/Earth Sciences courses, showing that not only access to theoretical content would favor their choices (as also demonstrated in another study) ${ }^{(24)}$.
While it was identified that evening courses had a higher chance of alcohol use compared to full-time courses, another study ${ }^{(23)}$ did not identify this difference. However, a higher frequency of tobacco and illicit drug use and simultaneous use of alcohol and other drugs was indicated among nighttime students ${ }^{(23)}$. Motivators for substance use often cited by college students are curiosity, support and social interaction, and relief from general life dissatisfactions (may be related to the profile of night school students, many of whom are workers) ${ }^{(23)}$.

To our knowledge, this was also the first study to investigate enrollment in courses corresponding to the first choice and the intention/doubts about changing courses, as well as their associations with the use of alcohol, tobacco, and illicit drugs. It has been shown that these dissatisfactions or doubts may be associated with health risk behaviors. Alcohol abuse has been reported to be associated with increased school omission/dropout/dissatisfaction and number of course repetitions among college students ${ }^{(21)}$.

Whereas college students who reported financial difficulties and lack of discipline/study habits were associated with higher chances of using the three substances, another study showed that, taking into account students' behavior in class, being late, absent, and having difficulties concentrating or completing 
assignments were independent predictors of moderate and high alcohol consumption $^{(2)}$. Given the sectional design of this study, it is not possible to assign causality between substance use and academic factors, suggesting prospective studies.

Similar to what was observed for the teacher-student relationship, another study observed significant associations between alcohol consumption and fights/discussions with friends, conflicts with parents, and fights/discussions with strangers ${ }^{(21)}$. On the other hand, more time spent outside class studying was associated with a lower chance of using the three substances, and other studies have also found that on days when students spent more time studying, fewer heavy drinking episodes were reported ${ }^{(25)}$. Religious movements, on the other hand, were associated with a $72 \%, 76.5 \%$ and $81.2 \%$ reduction in the chances of alcohol, tobacco and illicit drug use, respectively, corroborating the findings in the literature ${ }^{(26-27)}$.

Regarding the lower chance of use of the three substances in the advanced campuses, these are usually younger than the main campuses and, possibly, the culture of "university fun", in which the use of psychoactive substances is frequent, has not yet influenced these environments so much. Among the motivations and/or risk factors for alcohol, tobacco and illicit drug use in the university environment, the influence of the sociocultural environment (such as the influence of friends, curiosity, and the search for fun) has been shown to be a central element ${ }^{(28)}$.

Having the health services offered by the university itself as the preferred network for medical care was also not associated with better indicators on the use of alcohol, tobacco or illicit drugs, compared to students who cited the public network; and some dimensions of student assistance were also associated with a higher chance of using one of the substances, which may have occurred because student users more frequently seek the university's assistance services as a support unit. Again, considering the sectional design, it is not possible to attribute causality between substance use and, for example, participation in student assistance psychological care, suggesting prospective studies. In Australia, students with high alcohol consumption were $20 \%$ more likely to report psychological stress compared to those with lower levels of consumption ${ }^{(2)}$. Another study identified: college students who received medical advice to reduce alcohol consumption had a 5.6 times higher prevalence of alcohol abuse compared to those who did not receive such advice ${ }^{(29)}$. Thus, it is suggested that preventive actions aimed at the use of alcohol, tobacco and illicit drugs be reinforced within student assistance, since students are potential users. Moreover, it is important that health care (medical, psychological, dental, and nutritional) be based on the principles of health promotion and humanized care, enabling an efficient reception of students. As measures that can be adopted for the prevention of alcohol, tobacco and illicit drugs abuse, we suggest: education with skills training to better cope with stress, early detection of use, provision of scientific information, teacher/tutor programs trained to detect problems of this kind, and a larger workload for the subjects that address the use of psychoactive substances ${ }^{(27)}$.

It is worth noting that there are factors related to macrostructural aspects that may precede the entry of students into academic life, such as financial difficulties - this aspect needs to be taken into consideration, given the succession of problems in a chain that it involves and that needs to be repaired. Student assistance measures (qualitatively and quantitatively adequate), such as scholarships, services, and assistances, could balance such inequities and provide better health indicators.

The findings of this study point to unprecedented associations between academic factors and use of alcohol, tobacco and illicit drugs in college students. It should be considered whether some university movements gather profiles of students more prone to substance use or act as incentives to use, as well as evaluate consequences on academic and health dimensions. As previously mentioned, publications on the subject are still scarce and, when available, they evaluate only one or a few aspects of academic life, without a complete evaluation, despite the great international visibility and the great importance and social impact of the theme. Additionally, the sample of undergraduate students from Brazilian federal institutions was the most comprehensive known: this article provides information on institutions located throughout the national territory and relevant to public health, together with an expressive sample number. This theme has its recognition highlighted by the WHO, which encourages the Health Promoting Universities strategy.

\section{Study limitations}

Among the factors potentially influencing the responses of college students, we highlight memory, the academic moment experienced when filling out the questionnaire (pre/post exams, term load, end of semester, etc.) and the interpretation of the question presented (self-completion). Regarding the low response rate in this study (13.4\% of the population), it should be noted that in epidemiological studies, participants tend to differ from non-participants in some aspects, such as gender, socioeconomic status, available time and habits, as well as physical and mental health conditions. However, this participation bias has been pointed out as a greater limitation to the validity of prevalence studies than to association studies, as is the case of the present study. Furthermore, it is suggested that future research should adopt validated instruments on substance use and an approach on substance abuse.

\section{Contributions to Public Health Policies}

It has been identified that a number of academic factors are associated with the use of alcohol, tobacco, and/or illicit drugs. Knowing what is happening, how it is happening, and what can be done to improve the health of college students is a necessary and important public health strategy. Universities have the opportunity and responsibility to develop and implement the best available research evidence, setting a benchmark for other groups. We have highlighted which student profiles require greater attention from health professionals, professors, coordinators, and university administrators; and we have flagged preferred areas of intervention. All of this may help to develop strategies for preventing substance use among college students.

\section{CONCLUSIONS}

This study confirmed that academic factors are associated with the use of alcohol, tobacco and illicit drugs. We identified that important academic factors - such as length of academic experience, entry 
by quota, shift and area of the course, choice of a course that does not correspond to their first choice, intention or doubt in changing course, non-residence with the family, participation in university movements, time of extra-class dedication to studies, student assistance and difficulties with significant interference in academic life/context - are associated with the chances of alcohol, tobacco and/or illicit drug use. These findings contribute to the performance of nursing professionals in the development of policies (especially governmental, in higher education institutions and university towns), assistance and health promotion of college students.

\section{ACKNOWLEDGMENT}

To the National Association of Deans of Federal Higher Education Institutions and the National Forum of Pro-rectors for Community and Student Affairs for conducting the survey and making the data available; to the managers and servers of the educational institutions for mobilizing the survey; to the students for their participation; and to the Postgraduate Program in Nutrition Science and the Forestry Campus of the Federal University of Viçosa for the human resources.

\section{REFERENCES}

1. Mendes F, Lopes MJ. Health vulnerabilities: the diagnosis of freshmen from a Portuguese university. Texto Contexto Enferm. 2014;23(1):7482. https://doi.org/10.1590/S0104-07072014000100009

2. Tembo C, Burns S, Kalembo F. The association between levels of alcohol consumption and mental health problems and academic performance among young university students. PLoS One. 2017;12(6):1-13. https://doi.org/10.1371/journal.pone.0178142

3. Eckschmidt F, Andrade AG, Oliveira LG. Comparação do uso de drogas entre universitários brasileiros, norte-americanos e jovens da população geral brasileira. J Bras Psiquiatr. 2013;62(3):199-207. https://doi.org/10.1590/S0047-20852013000300004

4. Fernandes TF, Monteiro BMM, Silva JBM, Oliveira KM, Viana NAO, Gama CAP, et al. Uso de substâncias psicoativas entre universitários brasileiros: perfil epidemiológico, contextos de uso e limitações metodológicas dos estudos. Cad Saúde Coletiva. 2017;25(4):498-507. https://doi.org/10.1590/1414-462×201700040181

5. Slutske WS, Hunt-Carter EE, Nabors-Oberg RE, Sher KJ, Bucholz KK, Madden PAF, et al. Do college students drink more than their noncollege-attending peers? evidence from a population-based longitudinal female twin study. J Abnorm Psychol. 2004;113(4):530-40. https:// doi.org/10.1037/0021-843X.113.4.530

6. World Health Organization (WHO). Global status report on alcohol and health [Internet]. Geneva (Switzerland): WHO Press; 2011 [cited 2020 Dec 23]. 286 p. Available from: http://www.who.int/substance_abuse/publications/global_alcohol_report/msbgsruprofiles.pdf

7. Silva ÉC, Tucci AM. Padrão de consumo de álcool em estudantes universitários (calouros) e diferença entre os gêneros. Temas Psicol. 2016;24(1):313-23. https://doi.org/10.9788/TP2016.1-21

8. Colares V, Franca C. Estudo comparativo de condutas de saúde entre universitários no início e no final do curso. Rev Saúde Pública. 2008;42(3):420-7. https://doi.org/10.1590/S0034-89102008000300005

9. Davoren MP, Demant J, Shiely F, Perry IJ. Alcohol consumption among university students in Ireland and the United Kingdom from 2002 to 2014: a systematic review. BMC Public Health. 2016;16:173. https://doi.org/10.1186/s12889-016-2843-1

10. World Health Organization (WHO). Prevalence of tobacco smoking 2015 [Internet]. Geneva (Switzerland): WHO; 2017 [cited 2017 Nov 28 ]. Available from: http://apps.who.int/gho/data/node.sdg.3-a-viz?lang=en

11. World Health Organization (WHO). WHO global report on trends in prevalence of tobacco smoking 2015 [Internet]. Geneva (Switzerland): WHO Press; 2015 [cited 2020 Dec 23]. 359 p. Available from: https://apps.who.int/iris/bitstream/handle/10665/156262/9789241564922_ eng.pdf?sequence $=1$

12. Steptoe A, Wardle J, Cui W, Bellisle F, Zotti AM, Baranyai R, et al. Trends in smoking, diet, physical exercise, and attitudes toward health in European University Students from 13 Countries, 1990-2000. Prev Med. 2002;35(2):97-104. https://doi.org/10.1006/pmed.2002.1048

13. Health Sciences Descriptors. Illicit Drugs [Internet]. 2017 ed. São Paulo: BIREME/PAHO/WHO; 2017 [cited 2020 Dec 23]. Available from: https://decs.bvsalud.org/ths/resource/?id=24318\&filter=ths_termall\&q=Drogas\%20II\%C3\%ADcitas

14. Instituto Nacional de Estudos e Pesquisas Educacionais Anísio Teixeira. Censo da Educação Superior 2019: Divulgação dos resultados [Internet]. Brasília (Brasil): INEP; 2020 [cited 2021 Feb 19]. 82 p. Available from: https://download.inep.gov.br/educacao_superior/censo_ superior/documentos/2020/Apresentacao_Censo_da_Educacao_Superior_2019.pdf

15. Silva MCN, Machado MH. Sistema de Saúde e Trabalho: desafios para a Enfermagem no Brasil. Ciênc Saúde Coletiva. 2020;25(1):7-13. https:// doi.org/10.1590/1413-81232020251.27572019

16. Associação Nacional dos Dirigentes das Instituições Federais de Ensino Superior. A ANDIFES [Internet]. Brasília (Brazil): ANDIFES; 2020 [cited 2020 Dec 23]. Available from: http://www.andifes.org.br/institucional/andifes/

17. Associação Nacional dos Dirigentes das Instituições Federais de Ensino Superior. Fórum Nacional de Pró-reitores de Assuntos Comunitários e Estudantis [Internet]. Brasília (Brazil): ANDIFES; 2020 [cited 2020 Dec 23]. Available from: http://www.andifes.org.br/ forum-nacional-de-pro-reitores-de-assuntos-comunitarios-e-estudantis-fonaprace/ 
18. Associação Nacional dos Dirigentes das Instituições Federais de Ensino Superior, Fórum Nacional de Pró-reitores de Assuntos Comunitários e Estudantis. IV Pesquisa do Perfil Socioeconômico e Cultural dos Estudantes de Graduação das Instituições Federais de Ensino Superior Brasileiras [Internet]. Brasília (Brazil): ANDIFES; 2020 [cited 2020 Dec 23]. Available from: http://www.andifes.org.br/wp-content/ uploads/2017/11/Pesquisa-de-Perfil-dos-Graduanso-das-IFES_2014.pdf

19. Souza J, Hamilton H, Wright MGM. O desempenho acadêmico e o consumo de álcool, maconha e cocaína entre estudantes de graduação de Ribeirão Preto - Brasil. Texto Contexto Enferm. 2019;28(spe):e315. https://doi.org/10.1590/1980-265x-tce-cicad-3-15

20. Candido FJ, Souza R, Stumpf MA, Fernandes LG, Veiga R, Santin M, et al. The use of drugs and medical students: a literature review. Rev Assoc Med Bras. 2018;64(5):462-8. https://doi.org/10.1590/1806-9282.64.05.462

21. Castaño-Perez GA, Calderon-Vallejo GA. Problems associated with alcohol consumption by university students. Rev Latino-Am Enfermagem. 2014;22(5):739-46. https://doi.org/10.1590/0104-1169.3579.2475

22. Demenech LM, Dumith SC, Paludo SS, Neiva-Silva L. Academic migration and marijuana use among undergraduate students: evidences from a sample in southern Brazil. Ciênc Saúde Coletiva. 2019;24(8):3107-16. https://doi.org/10.1590/1413-81232018248.27292017

23. Andrade AG, Duarte PCAV, Oliveira LG. I Levantamento Nacional sobre o Uso de Álcool, Tabaco e Outras Drogas entre Universitários das 27 Capitais Brasileiras [Internet]. Brasília (BR): SENAD; 2010 [cited 2020 Dec 23]. 284 p. Available from: https://cetadobserva.ufba.br/sites/ cetadobserva.ufba.br/files/634.pdf

24. Rodríguez-Muñoz PM, Carmona-Torres JM, Rodríguez-Borrego MA. Influência do consumo de tabaco e álcool, de hábitos alimentares e atividade física em estudantes de enfermagem. Rev Latino-Am Enfermagem. 2020;28:e3230. https://doi.org/10.1590/1518-8345.3198.3230

25. Greene KM, Maggs JL. Academic time during college: Associations with mood, tiredness, and binge drinking across days and semesters. J Adolesc. 2017;56:24-33. https://doi.org/10.1016/j.adolescence.2016.12.001

26. Guidorizzi ZAC, Cumsille F, Robert M. A associação entre o uso de álcool, maconha e cocaína e as características sociodemográficas de universitários de Ribeirão Preto, Brasil. Texto Contexto Enferm. 2019;28(spe):e110. https://doi.org/10.1590/1980-265x-tce-cicad-1-10

27. Silva LVER, Malbergier A, Stempliuk VA, Andrade AG. Fatores associados ao consumo de álcool e drogas entre estudantes universitários. Rev Saude Publica. 2006;40(2):280-8. https://doi.org/10.1590/S0034-89102006000200014

28. Balthazar EB, Gaino LV, Almeida LY, Oliveira JL, Souza J. Risk factors for substance use: perception of student leaders. Rev Bras Enferm. 2018;71(Suppl5):2116-22. https://doi.org/10.1590/0034-7167-2017-0587

29. Pedrosa AASS, Camacho LAB, Passos SRL, Oliveira RVC, Oliveira RVC, Antonio A, et al. Consumo de álcool entre estudantes universitários. Cad Saude Publica. 2011;27(8):1611-21. https://doi.org/10.1590/S0102-311X2011000800016 